\title{
Removal of Heavy Metals from Wastewater in Hawassa Textile Factory Treatment Ponds by Shoenoplectus Lacustris: Opportunity of Phytoremediation by Aquatic Macrophyte
}

\author{
Iyasu Gudisa \\ School of Natural and Computational Science, Madda Walabu University, Ethiopia
}

\begin{abstract}
A phytoremediation study was made on Hawassa Textile Factory Treatment ponds to assess the potential of Shoenoplectus lacustris to accumulate heavy metals in the plant tissues with reference to water. To achieve the objectives of this study, roots and shoots of Shoenoplectus lacustris along with surface water in the two treatment ponds having the macrophyte at their shoreline were analyzed by EPA standard methods for six heavy metals, i.e., $\mathrm{Cd}, \mathrm{Cr}, \mathrm{Cu}, \mathrm{Pb}, \mathrm{Mn}$ and $\mathrm{Zn}$. The results showed that the concentration of heavy metals were higher in macrophytes than water. The accumulation of heavy metals in water and in the macrophytes had the same pattern with descending order of $\mathrm{Zn}>\mathrm{Mn}>\mathrm{Cu}>\mathrm{Cr}>\mathrm{Cd}$ while $\mathrm{Cu}$ and $\mathrm{Zn}$ were more accumulated in macrophytes. Lead was below detection in all samples analyzed for heavy metals. There were significant differences in accumulation of the different heavy metals in roots and shoots of Shoenoplectus lacustris. Results from both ponds showed that higher heavy metals accumulation generally occurred in the root of Shoenoplectus lacustris than the shoot. However, the shoot accumulated higher concentration of Mn than the root. Therefore, the present study revealed that Shoenoplectus lacustris can serve as bioremediant due to its ability to remove heavy metals from contaminated water and accumulate in its roots and shoots thereby improving water quality. Thus, in order to improve the efficiency of biological lagoons constructed for the treatment of the city sewage industry wastes, it is very important to growth the Shoenoplectus lacustris.
\end{abstract}

Keywords: Heavy metals, Bioremediant, Macrophytes, Phytoremediation, Ponds, Textile factory

DOI: $10.7176 /$ JEES/9-4-02

Publication date: April $30^{\text {th }} 2019$

\section{Introduction}

The textile factory wastewater releases high heavy metals concentration that could be severe pollution potentials since the parameters measured have values above the tolerable limits (Deepali and Gangwar, 2010; Sivakumar et. al, 2011; Ahmed et. al, 2012 ). The Metal pollution affects different organisms in different ways and has different degree of the impacts (Stan et. al, 2011; Pudpong and Chantangsi, 2015; Anusha et. al, 2017). A continuous discharge of high level of heavy metals from Textile Factory Effluent into aquatic ecosystem causes serious water pollution because of their extreme toxicity at high concentration and because they cannot easily be disintegrated or decomposed and can be bioaccumulated along food chain and food web. Thus, the release of heavy metals into the aquatic ecosystem through industrial effluents is a major concern, worldwide and removal of such pollutants has been a great concern during last decades (Malakootian, 2009). Therefore, it turns out to be necessary to use different methods to reduce their concentration to acceptable levels before discharging them into the environment. The biological treatment (phytoremediation) is one of the way to reduce the heavy concentration from the effluent before it is exposed to the environment.

Interest in phytoremediation as a method to solve environmental contamination has been growing rapidly in recent years. Phytoremediation involves growing plants to remove heavy metals from environment by degradation (detoxification) of the pollutants. It is an emerging technology that uses various plants to degrade, extract, contain, or immobilize contaminants from soil and water. This technology has been receiving attention lately as an innovative, cost-effective alternative to the more established treatment methods used at hazardous waste sites. The macrophytes growing on the shore of waste water treatment ponds are expected to accomplish this remediation (the removal of the heavy metals from the effluent) (Melinda et. al., 2013; Chowdhury et. al., 2015).

The recent studies assessed the heavy metals removal potentials of other Shoenoplactus species macrophytes from Lake Hawassa by Tigist Ashagire et. al (2011) and Solomon Sorsa et. al. (2014) revealed the ability of aquatic macrophytes to remove heavy metals from contaminated water and sediments. This study, therefore, is oriented towards low cost and eco-friendly way of removing heavy metals by using Shoenoplactus lacustris on the shore of effluent treatment ponds of Hawassa Textile Factory, which will be beneficial for community. Concentrations of different heavy metals in water and tissue of Shoenoplectus lacustris (growing on the shore of the treatment pond) was determined to know the role of the macrophytes in removing pollutants from industrial effluents. Hawassa Textile Factory is one of such factory whose effluent treatment pond is colonized by, Shoenoplectus lacustris, the macrophytes get attention in removing heavy metals from the effluents. 
Thus, this investigation was planned and executed to assess the potential of Shoenoplectus lacustris as biological filters in improving removing heavy metals.

\section{Materials and Methods}

The Hawassa Textile Factory was established in 1989 by the Ethiopian government, the largest Factory among the cluster of factories lined in the Eastern edge of the Hawassa city. The effluent from the Hawassa Textile factory is routed by way of underground concrete pipe to treatment ponds (biological lagoons) located $1.5 \mathrm{~km}$ from the enterprise. The biological lagoon consists of two big and two small ponds surrounded by farm land and villages. The two small ponds, labeled as pond 1 and pond 2 in this study, have shoreline covered by Shoenoplectus lacustris. The two ponds having Shoenoplectus lacustris in their shorelines were taken as sampling sites. Samples of water and aquatic macrophytes were concurrently taken from the same sampling points of sampling site. After, rinsing the sampling bottles with acids and water, one liter of composite water sample was taken from each pond at approximately 10-20 cm depth of water column. This was done because the top of surface water may be contaminated with heavy metals from the environment. The samples of water were stored in refrigerator at $4^{\circ} \mathrm{C}$. Then, water samples were digested using EPA standard method 3010A (1992). Finally, the digested samples were analyzed by Flame Atomic Absorption Spectrophotometer (FAAS). The composite sample of Shoenoplectus lacustris were also uprooted from the same place or point where water was taken for both ponds. The plant samples were washed with distilled water to remove sediment particles and other contaminants such as heavy metals which came from external environment. These parts of plants were put in the oven at $80{ }^{\circ} \mathrm{C}$ for $48 \mathrm{hrs}$ for drying and powdered. Finally, powdered plant samples were stored in the plastic bags for heavy metal analysis by Flame Atomic Absorption Spectrophotometer (FAAS). The data analysis was carried out with the SPSS 20 version statistical programme. T-test, and descriptive statistics such as mean value; minimum and maximum values were used in the study. Pearson correlation coefficient analysis was done between heavy metals concentration in one media and their concentration in other media to check the influence of their concentrations in one media on their concentrations in other media.

\section{RESULTS}

\subsection{Heavy metal concentrations in the Treatment Ponds of Hawassa Textile Factory}

The detectable heavy metal concentrations in composite samples water and macrophytes were shown in Table 1. Except lead $(\mathrm{Pb})$ all analyzed heavy metals were detectable in both water, and aquatic plants for both pond 1 and pond 2. The mean concentration $(\mathrm{mg} / \mathrm{L})$ of heavy metals in water samples in descending order were $\mathrm{Mn}>\mathrm{Zn}>$ $\mathrm{Cu}>\mathrm{Cr}>\mathrm{Cd}$ in pond 1 while $\mathrm{Zn}>\mathrm{Mn}>\mathrm{Cu}>\mathrm{Cr}>\mathrm{Cd}$ in pond 2 (Fig.1).

The mean concentrations of $\mathrm{Cr}, \mathrm{Cu}, \mathrm{Mn}$ and $\mathrm{Zn}$ were significantly higher in pond 1 than in pond 2 while the mean value of cadmium concentration was slightly higher in pond 1 than their concentrations in pond 2 . The comparison of studied heavy metal concentrations in water showed as the fig. 1 .

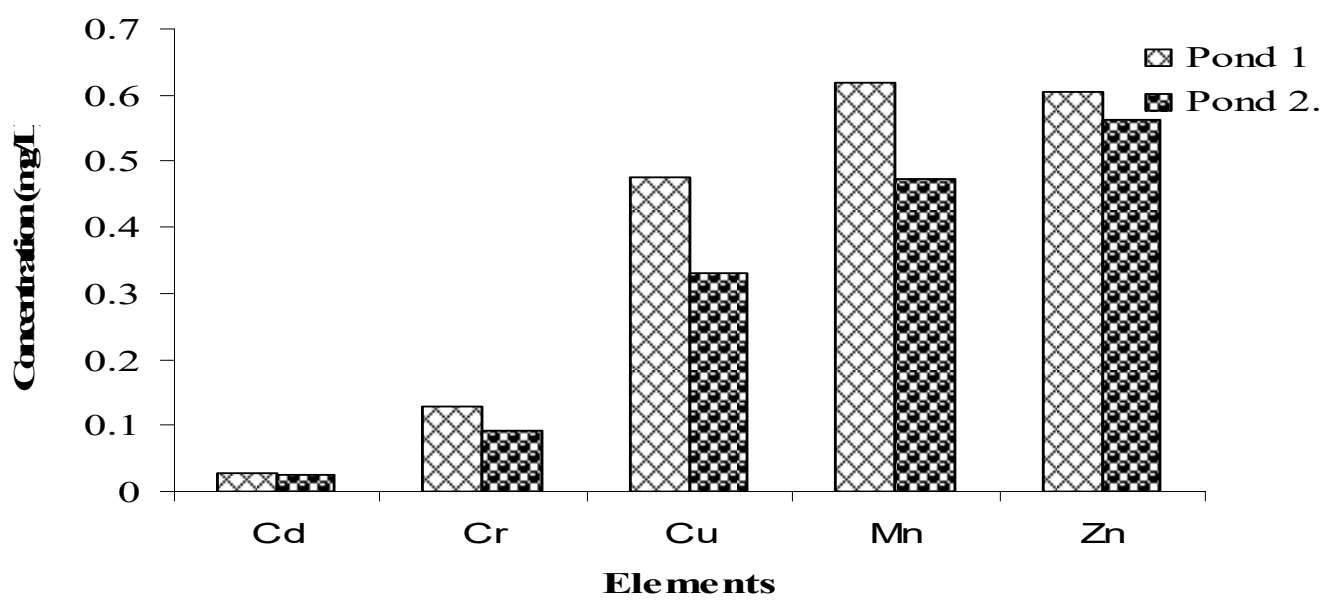

Figure 1: Comparison of heavy metal concentrations mean in water in Hawassa Textile Factory Treatment of Ponds (pond 1 and pond 2)

\subsection{Heavy metal concentrations in the aquatic plants (Shoenoplectus lacustris)}

Mean heavy metal concentrations $(\mathrm{mg} / \mathrm{Kg})$ in Schoenoplectus lacustris in descending order was $\mathrm{Mn}>\mathrm{Zn}>$ $\mathrm{Cu}>\mathrm{Cr}>\mathrm{Cd}$ in pond 1 and $\mathrm{Zn}>\mathrm{Mn}>\mathrm{Cu}>\mathrm{Cr}>\mathrm{Cd}$ pond 2 (Fig. 2). The mean concentrations (mg/Kg dry wt.) of the individual heavy metals in the Shoenoplectus lacustris were $160.4 \pm 13.1$ for $\mathrm{Zn}, 165.5 \pm 13.4$ for $\mathrm{Mn}, 52.4 \pm 3.3$ for $\mathrm{Cu}, 4.87 \pm 0.37$ for $\mathrm{Cr}$ and $0.921 \pm 0.09$ for $\mathrm{Cd}$ in pond 1. Likewise, the mean concentrations (mg/Kg dry wt) of 
heavy metals in pond 2 were $153.1 \pm 13.8$ for $\mathrm{Zn}, 141.6 \pm 12.8$ for $\mathrm{Mn}$, ` $42 \pm 1.9$ for $\mathrm{Cu}, 7.014 \pm 0.37$ for $\mathrm{Cr}$ and $0.730 \pm 094$ for $\mathrm{Cd}$. The concentrations of $\mathrm{Cu}, \mathrm{Zn}$ and $\mathrm{Mn}$ in the Shoenoplectus lacustris in pond 1 were significantly $(\mathrm{P}<0.05)$ higher than the concentrations in pond 2.

Mean concentrations of Heavy metals in water and macrophyte (Shoenoplectus lacustris) taken from the two treatment ponds of the Hawassa Textile Factory are summarized in the Table 2. The Table clearly revealed that enormously high concentrations of heavy metals were generally accumulated in macrophyte as compared to the water.

Table 2 Comparison of heavy metals among the different media (water and macrophytes

\begin{tabular}{|c|c|c|c|c|}
\hline \multicolumn{2}{|c|}{ Heavy metals Water $(\mathrm{mg} / \mathrm{L})$} & \multicolumn{2}{c|}{ Macrophyte $($ S. lacustris $)(\mathrm{mg} / \mathrm{Kg}$ dry wt $)$} \\
\hline & Pond 1 & Pond 2 & pond 1 & Pond 2 \\
\hline $\mathrm{Cd}$ & $0.027 \pm 0$ & $0.025 \pm 0$ & $0.921 \pm 0.09$ & $7.01 \pm 0.37$ \\
\hline $\mathrm{Cr}$ & $0.127 \pm 0.02$ & $0.094 \pm 0$ & $4.87 \pm 0.37$ & $42 \pm 1.88$ \\
\hline $\mathrm{Cu}$ & $0.475 \pm 0.01$ & $0.330 \pm 0.01$ & $52.35 \pm 3.3$ & ND \\
\hline $\mathrm{Pb}$ & $\mathrm{ND}$ & $\mathrm{ND}$ & $\mathrm{ND}$ & $141.6 \pm 12.8$ \\
\hline $\mathrm{Mn}$ & $0.619 \pm 0.04$ & $0.474 \pm 0.01$ & $165.5 \pm 13.4$ & $153.1 \pm 13.8$ \\
\hline $\mathrm{Zn}$ & $0.605 \pm 0.01$ & $0.562 \pm 0.01$ & $160.4 \pm 13.1$ & \\
\hline
\end{tabular}

\subsection{Comparison of heavy metals concentration in roots and shoots of the plants}

Mean heavy metal concentrations $(\mathrm{mg} / \mathrm{Kg})$ in root of Shoenoplectus lacustris in descending order was $\mathrm{Zn}>$ $\mathrm{Mn}>\mathrm{Cu}>\mathrm{Cr}>\mathrm{Cd}$ in both ponds (Table 3). The order of heavy metals concentration in the shoot of the plant was the same with water (i.e. $\mathrm{Mn}>\mathrm{Zn}>\mathrm{Cu}>\mathrm{Cr}>\mathrm{Cd}$ ) in both pond 1 and pond 2 (Table3). Results from both ponds showed that higher heavy metals accumulation generally occurred more in the root than the shoot of the plants. However, the shoot accumulated higher concentration of $\mathrm{Mn}$ than root, but the concentration of Cadmium in plant shoot and plant root was almost equal.

Table 3 comparison of heavy metals concentrations in plant root and plant shoot

\begin{tabular}{|c|c|c|c|c|c|}
\hline \multirow{2}{*}{$\begin{array}{c}\text { Heavy } \\
\text { metals }\end{array}$} & \multicolumn{2}{|c|}{ Root } & \multicolumn{2}{|c|}{ Shoot } & $\begin{array}{l}\text { Critical range in plants } \\
\text { (Kumar } \text { et al., 2007) }\end{array}$ \\
\cline { 2 - 5 } & Pond 1 & Pond 2 & Pond 1 & Pond 2 & \\
\hline $\mathrm{Cd}$ & $0.920 \pm 0.094$ & $0.920 \pm .094$ & $0.920 \pm 0.1$ & $0.539 \pm 0$ & $0.01-0.03$ \\
\hline $\mathrm{Cr}$ & $6.370 \pm 0.74$ & $9.372 \pm 0.74$ & $3.368 \pm 0$ & $4.655 \pm 0$ & $0.081-0.37$ \\
\hline $\mathrm{Cu}$ & $71.664 \pm 2.67$ & $43.861 \pm 2.86$ & $33.035 \pm 4$ & $19.956 \pm 0.91$ & $0.025-0.09$ \\
\hline $\mathrm{Pb}$ & $\mathrm{ND}$ & $\mathrm{ND}$ & $\mathrm{ND}$ & $\mathrm{ND}$ & $0.03-0.3$ \\
\hline $\mathrm{Mn}$ & $154.1 \pm 13.5$ & $128.9 \pm 13$ & $156.9 \pm 13.4$ & $154.3 \pm 15.3$ & - \\
\hline $\mathrm{Zn}$ & $164.3 \pm 12.5$ & $184.4 \pm 14.2$ & $144.6 \pm 13.7$ & $122.1 \pm 11.9$ & $0.1-0.4$ \\
\hline
\end{tabular}

\subsection{Correlation of heavy metals concentration in water and plant shoots and roots}

The correlation analysis was used to infer whether there was a correlation between heavy metal concentrations in water, plant shoots and roots. The correlation of heavy metal concentrations among the different media (water and macrophyte) is presented in Table 5.

Accordingly, $\mathrm{Cd}$ concentration in plant root and plant shoot highly correlated. $\mathrm{Cr}$ concentrations in the water is negatively correlated with that in plant root and shoot. Likewise the $\mathrm{Cr}$ concentration in the root was strongly and positively correlated with that in the shoot. $\mathrm{Cu}$ concentration in water is very strongly and positively correlated with that in the plant shoot and root. Mn concentration in the water is strongly positive with that in plant root. Considering $\mathrm{Zn}$, its concentration in water was strong and positive with that in the plant root whereas the concentration in the water strongly negative with that of concentration in plant shoot. But its concentration correlation in plant root and shoot was strong and positive. 
Table 5 Bivariate correlation coefficient of analyzed heavy metals in wastewater, macrophytes and sediment $(\mathbf{n}=6)$.

\begin{tabular}{|c|c|c|c|c|c|}
\hline & & & Water & Plant root & Plant shoot \\
\hline \multirow{3}{*}{$\mathrm{Cd}$} & Sediment & $R$ & $0.612 *$ & & \\
\hline & Plant root & $R$ & 0.5 & 1 & \\
\hline & Plant shoot & $R$ & $0.68^{*}$ & $0.947 * *$ & \\
\hline \multirow{3}{*}{$\mathrm{Cr}$} & Sediment & $r$ & $-0.711 *$ & & \\
\hline & Plant root & $r$ & $-0.711 *$ & 1 & \\
\hline & Plant shoot & $\mathrm{r}$ & $-0.894^{*}$ & $0.927 * *$ & 1 \\
\hline \multirow{3}{*}{$\mathrm{Cu}$} & Sediment & $r$ & $0.704^{*}$ & & \\
\hline & Plant root & $r$ & $0.957 * *$ & 1 & \\
\hline & Plant shoot & $r$ & $0.931 * *$ & $0.924 * *$ & 1 \\
\hline \multirow{3}{*}{ Mn } & Sediment & $r$ & -0.413 & & \\
\hline & Plant root & $\mathrm{r}$ & $0.874 *$ & 1 & \\
\hline & Plant shoot & $r$ & 0.363 & 0.408 & 1 \\
\hline \multirow[b]{3}{*}{$\mathrm{Zn}$} & Sediment & $r$ & $0.768^{*}$ & & \\
\hline & Plant root & $r$ & $0.868 *$ & 1 & \\
\hline & Plant shoot & $r$ & $-0.983 * *$ & $0.934 * *$ & 1 \\
\hline
\end{tabular}

* Correlation is significant at the 0.05 level (2-tailed).

** Correlation is significant at the 0.01 level (2-tailed).

\section{DISCUSSION}

\subsection{Heavy metal concentrations in waste water / effluent}

The present study has shown that $\mathrm{Cd}, \mathrm{Cr}, \mathrm{Cu}, \mathrm{Mn}$ and $\mathrm{Zn}$ concentrations in the effluent were lower than maximum permissible limits provided by EPA (2003). This might be due the fact that most metals were absorbed and adsorbed by aquatic plants. Even though the concentrations of heavy metals recorded in this study from study area fall below EPA maximum permissible limits, their concentrations are 6 to 130 times higher than the values from the same pond in 2002 by Zinabu G/Mariam and Zerihun Desta (2002). On the other hand, the concentration of $\mathrm{Mn}$ and $\mathrm{Zn}$ were very high when compared with the concentrations of the other heavy metals. Oyew and Don-podro (2003) reported that the concentration of Mn in Textile Factory effluent high next to Zinc. These authors have pointed out that $\mathrm{Mn}$ and $\mathrm{Zn}$ are widely used in industry to make dyes. As a result, these metals concentration is high in Textile Factory effluent).

\subsection{Heavy metal concentrations in aquatic macrophytes}

Aquatic plants are different both in capacity to take up metals in the root tissues and in the proportion of metals transferred to shoot parts (Baldantoni et al., 2004). In this study, the $\mathrm{Zn}$ was highest among the metals determined in Shoenoplectus lacustris. This might be due to it is one of the most soluble and mobile of the trace metal cations. As a result, transportation from soil to root to shoots of plants is very high (Rout and Das, 2003). Mn determined from Shoenoplectus lacustris of this study was the second highest next to $\mathrm{Zn}$. This is might be because it is an essential element for plants necessary in many redox processes and in photosynthesis (Memon et al., 2001; Carranza-A' lvarez et al. (2008). Even though $\mathrm{Cd}$ is not an essential element for metabolic processes and cumulative poison, Kabata-Pendias and Pendias (1992) reported that both root and leaf absorbed Cd effectively. Demirezen and Aksoy (2004) reported that Cd accumulated at lowest level in Typha angustifolia in Sultan Marsh. Similarly, this study also revealed lowest Cd concentration in Shoenoplectus lacustris. As indicated by Kabata-Pendias and Pendias (1992) cited in Kumar et al., (2008) the critical ranges of Cadmium, Chromium, Copper and Zinc in plants are 0.01-0.03, 0.025-0.09, 0.03-0.3 and 0.1-0.4 mg/Kg respectively (Table 4). All heavy metals concentrations detected in Shoenoplectus lacustris in the present study for the different heavy metals are above the critical range stated by these authors. This is a sign how much Shoenoplectus lacustris removes and accumulates heavy metals from environment per $\mathrm{kg}$ of biomass. Therefore, as the biomass of the plant increases, high amount of heavy metals can be removed from environment.

\subsection{Comparison of heavy metals concentrations between media}

The concentrations of heavy metals in general follows the sequence plant root $>$ plant shoot $>$ water in the decreasing order. This shows the capacity of Shoenoplectus lacustris to accumulate these heavy metals in high amount than its concentration in water. But, the heavy metals concentration in macrophytes is the outcome of the long period of time accumulation while the concentration of heavy metals in water is the representative of only for instant time in which the water comes and passes. The high concentration of $\mathrm{Cd}$ (non-essential element) in this study shows how much Shoenoplectus lacustris removes heavy metals from the environment. Even if this 
metal is non-essential, Shoenoplectus lacustris removes higher concentration than water. The Cr concentration in macrophyte are much higher than its concentration in water. This also exhibits the potential of Shoenoplectus lacustris for removal of $\mathrm{Cr}$ from effluent. The concentration of $\mathrm{Cu}$ in Shoenoplectus lacustris is higher than its concentration in water. This may be attributed to high $\mathrm{Cu}$ requirement for various enzyme activities, key roles in photosynthesis and growth of the plant (Tripathi et al., 1997; Hopkins, 1999).

\subsection{Comparison of heavy metals concentration in plant roots and plant shoots}

The heavy metals concentrations in roots and shoot of Shoenoplectus lacustris of this study presented in Table 4. The results showed that except Mn, heavy metal concentrations in Shoenoplectus lacustris were much higher in roots than shoots $(\mathrm{p}<0.05)$ and the similar results were reported by Meepring $(2003)$ and Baldantoni et al., (2004). Deng et al. (2004) explained that plants species and populations differ widely in their ability to accumulate significantly greater concentrations of metals in roots than shoots, indicating high plant availability of the substrate metals as well as its limited mobility once inside the plant. But manganese is more accumulated in the shoot as reported by Yap et al. (2009).

Emergent and terrestrial plant species accumulate high concentrations of metals in their roots under natural conditions but much less so in their shoots, and the accumulation increased further with increased external concentration (Deng et al., 2004). A similar trend was observed in the present study in that heavy metal concentrations analyzed from root of Shoenoplectus lacustris was generally higher than the shoot. This suggests that roots of Shoenoplectus lacustris are the main compartment for metal accumulation. However, even though $\mathrm{Mn}$ concentrations were higher than zinc in water, sediment and shoot of Shoenoplectus lacustris, Zn concentration was higher than Mn concentration in the plant root. This indicates that $\mathrm{Mn}$ is accumulated more in the shoot while zinc is accumulated more in the root of Shoenoplectus lacustris.

\subsection{Correlation of heavy metals in water, plant root and plant shoot}

The correlation analysis was used to infer whether there was a correlation between heavy metal concentrations in water, plant shoots and roots. . Absence of correlation between concentrations of the metal in the media shows independence of the metal concentration in one medium from the concentrations of that metal in other medium. . The negative $\mathrm{Cr}$ and $\mathrm{Zn}$ concentration correlation between plant shoots and water supports theory says the rooted plants receive the heavy metals from the sediment because if heavy metals do not separate from the water column and precipitate, they are not available for rooted plants up taking (Jackson, 1998). The presence of positive correlation suggests the same direction of accumulation. In this regard the positively strong relationship of $\mathrm{Cr}$ and $\mathrm{Zn}$ concentration in sediment, plant shoots and plant root is showed translocation and accumulation from sediment in plant parts. Most of the time heavy metals present in water slowly precipitate and accumulate in the sediment. Then the sedimented heavy metals are taken by the aquatic plant roots and translocated to the other plant organs, in this study shoot of Shoenoplectus lacustris). Here the heavy metals flow from sediment to plant roots, from the plant roots translocated to plant shoots.

\section{CONCLUSION AND RECOMMENDATIONS}

\subsection{CONCLUSION}

Generaaly, the heavy metals concentration, in the media of the Hawassa Textile Factory Treatment Ponds followed the order: plant root $>$ plant shoot $>$ water. The concentration of the heavy metals have shown that Shoenoplectus lacustris is good absorbent of $\mathrm{Mn}, \mathrm{Zn}$ and $\mathrm{Cu}$. Except the concentration of $\mathrm{Mn}$, the concentration of all the analyzed heavy metals in plant root showed positive and strong correlattion with their concentrations in plant shoot.

\subsection{RECOMMENDATIONS}

In view of the contents of some physic-chemical parameters in the pond water of the factory should be pay attention to improve the microbial activity and oxidation capacity of the ponds by lower the pollutant level to an acceptable concentration before discharges its effluents into the swamp. Since the Shoenoplectus lacustris was the only macrophyte found growing on shoreline and limited to two treatment ponds only, it was not possible to show detailed variation and make comparison with more sites and other candidate macrophytes. Therefore, further study needed to and include other macrophytes such as Typha latifolia commonly found on littoral area of Lake Hawassa and evaluate their ability to serve as bioremediant. In order to improve the efficiency of biological lagoons constructed for treatment of any effluent, we can growth Shoenoplectus lacustris that will serve as biofilters by giving protection for nearby wetland, running and standing water bodies. . The aquatic plant Shoenoplectus lacustris, which showed its ability to accumulate heavy metals in its body parts including shoot system from the treatment ponds of Hawassa Textile Factory, could also be a potential threat to livestock and human health it is not properly removed or disposed. As the biological treatment ponds are located in the middle of rural residential area, the heavy metals can be consumed by domestic animals; i.e. introduced into food 
chain and ultimately reaches to human being. Therefore, the community should avoid the livestock from grazing this plant and be aware of the health hazards of toxic heavy metals that can be biomagnified through food chain.

\section{REFERENCES}

Annie Melinda Paz-Alberto1, Gilbert C. Sigua2*. (2013). Phytoremediation: A Green Technology to Remove Environmental Pollutants. American Journal of Climate Change., 2, 71-86

Anusha W.A.; Wickramasinghe1 D.L; Valentine; K. Mubiana2 and Ronny Blust., 2017. The effects of heavy metal concentration on bio-accumulation, productivity and pigment content of two Species of marine macro algae. Sri Lanka J. Aquat. Sci. 22(1) (2017): 1-8

Baldantoni, D.; Alfani, A.; Tommasi, P.D.; Bartoli, G. and Santo, A.V., 2004. Assessmen macro and microelement accumulation capability of two aquatic plants. Environmental

Deepali, K and Gangwar K, 2010. Metals Concentration in Textile and Tannery Effluents, Associated Soils and Ground Water. New York Science Journal.3 (4) Pollution.130:149-156.

Demirezen, D.; Aksoy, A., 2004. Accumulation of heavy metals in Typha angustifolia (L.) and Potamogeton pectinatus (L.) living in Sultan Marsh (Kayseri Turkey). Chemosphere 56, 685-696.

Deng, H.; Ye, Z.H.; Wong, M.H., 2004. Accumulation of lead, zinc, copper and cadmium by 12 wetland plant species thriving in metal-contaminated sites China. Environmental Pollution. 132: 29-40.

Environmental Protection Authority, 2003. Provisional Standards for Industrial Pollution Control in Ethiopia. Prepared under the ecologically sustainable industrial development (ESID) project US/ETH/99/068/Ehiopia, EPA/UNIDO, Addis Ababa.

Fernandez, J.C. and Henriquez, F.S.,1991. Biochemical, physiological and structural effect of excess copper in plants. Botanical Review. 57: 246-273.

Hart, R.; Welch, M.; Wendell A.; Norvell, L. A.; Sullivan’L., and Leon V.; Kochian. ,1998. Characterization of Cadmium Binding, Uptake, and Translocation in Intact Seedlings of Bread and Durum Wheat Cultivars. Plant Physiol. 116, (1). 1413-1420.

Jackson, L.J., 1998. Paradigms of metal accumulation in rooted aquatic vascular plants. The Science of the Total Environment. 219. 223-231.

Kabata-Pendias, A. and Pendias, H.,1992. Trace Elements in Soils and Plants. 2nd edition. CRC Press, Boca Raton, Fla.

Kalis, E.J. Temminghoff, E.J.; Visser, A. and Riemsdijk, W.H. Van.,2007. Metal uptake by Lolium perenne in contaminated soils using a four-step approach. Environmental Toxicology and Chemistry .26:335-345.

MacFarlane, G.R.and Burchett, M.D., 2002. Toxicity, growth and accumulation relationships of copper lead and zinc in the grey mangrove Avicennia marina (Forsk.) Vierh. Marine Environmental Research 54:65-84.

Malakootian, M; Nouri, J; Hossaini, H. 2009. Removal of heavy metals from paint industries

Wastewater using Leca as an available adsorbent. Tehran, Iran .Int. J. Environ. Sci. Tech. , spring. 6 (2), 183-190.

Meepring, A., 2003. The study on capability of different vetiver grass ecotypes to uptake the heavy metal contaminated soil. Master's thesis, Faculty of Graduate Studies, Mahidol University.

Memon, A.R.; Aktoprakligu 1, D.; Zdemur, A.; Verti, A.,2001. Heavy metal accumulation and detoxification mechanisms in plants. Turkish Journal of Botany .25: 111-121.

Rout, G.R., and P. Das., 2003. Effect of metal toxicity on plant growth and metabolism: Zinc. Agronomie 23:311.

Sivakumar, k.k; Balamurugan, C.; Ramakrishnan and Leena Hebsi Bhai, 2011. Assessment studies on wastewater pollution by textile dyeing and bleaching industries at karur, tamil nadu..J.Chem. Vol.4, No.2 (2011), 264-269.

Tigist Ashagre Amare*, Girma Tilahun Yimer and Kassaye Balkew Workagegn. ,2014. Assessment of Metals Concentration in Water, Sediment and Macrophyte Plant Collected from Lake Hawassa, Ethiopia. Journal of Environmental \& Analytical Toxicology. 5(1).

Yap D.W.; Adezrian, J.; Khairiah, J; Ismail, B.S. and Ahmad-Mahi, R., 2009. The Uptake of Heavy Metals by Paddy Plants (Oryza sativa) in Kota Marudu, Sabah, Malaysia.

Zinabu Gebre-Mariam and Zerihun Desta.,2002. SINET: Ethiop. J. Sci., 25(2):263-274. 